\title{
Ethylene Response Factor Sl-ERF.B.3 Is Responsive to Abiotic Stresses and Mediates Salt and Cold Stress Response Regulation in Tomato
}

\author{
Imen Klay, ${ }^{1,2,3}$ Julien Pirrello, ${ }^{2,3}$ Leila Riahi, ${ }^{4}$ Anne Bernadac, ${ }^{2,3}$ Ameur Cherif, ${ }^{4}$ \\ Mondher Bouzayen, ${ }^{2,3}$ and Sadok Bouzid ${ }^{1}$ \\ ${ }^{1}$ Laboratoire de Morphogenèse et de Biotechnologie Végétale, Faculté des Sciences de Tunis (FST), \\ Campus Universitaire 2092 El Manar Tunis, Tunisia \\ ${ }^{2}$ Université Toulouse, INP ENSA Toulouse, 31326 Castanet-Tolosan, France \\ ${ }^{3}$ INRA, 31326 Castanet-Tolosan, France \\ ${ }^{4}$ LR Biotechnologie et Valorisation des Bio-Géo Ressources (LR11ES31), Institut Supérieur de Biotechnologie, \\ Université de La Manouba Biotech Pole de Sidi Thabet, Sidi Thabet, 2020 Ariana, Tunisia
}

Correspondence should be addressed to Imen Klay; imenklay@voila.fr

Received 27 March 2014; Revised 6 June 2014; Accepted 8 July 2014; Published 6 August 2014

Academic Editor: Chang Won Choi

Copyright (C) 2014 Imen Klay et al. This is an open access article distributed under the Creative Commons Attribution License, which permits unrestricted use, distribution, and reproduction in any medium, provided the original work is properly cited.

Sl-ERF.B.3 (Solanum lycopersicum ethylene response factor B.3) gene encodes for a tomato transcription factor of the ERF (ethylene responsive factor) family. Our results of real-time RT-PCR showed that Sl-ERF.B.3 is an abiotic stress responsive gene, which is induced by cold, heat, and flooding, but downregulated by salinity and drought. To get more insight into the role of Sl-ERF.B.3 in plant response to separate salinity and cold, a comparative study between wild type and two Sl-ERF.B.3 antisense transgenic tomato lines was achieved. Compared with wild type, Sl-ERF.B.3 antisense transgenic plants exhibited a salt stress dependent growth inhibition. This inhibition was significantly enhanced in shoots but reduced in roots, leading to an increased root to shoot ratio. Furthermore, the cold stress essay clearly revealed that introducing antisense Sl-ERF.B.3 in transgenic tomato plants reduces their cell injury and enhances their tolerance against $14 \mathrm{~d}$ of cold stress. All these results suggest that Sl-ERF.B.3 gene is involved in plant response to abiotic stresses and may play a role in the layout of stress symptoms under cold stress and in growth regulation under salinity.

\section{Introduction}

Plants are frequently exposed to a plethora of stress conditions such as low temperature, salt, drought, flooding, heat, oxidative stress, and heavy metal toxicity. Abiotic stress often leads to plant growth inhibition and limits crop productivity [1]. It has been estimated that abiotic stresses were the principal cause of decreasing the average yield of major crops by more than $50 \%$ [2]. To confront such environmental aggressions, plants develop adaptive responses at physiological and molecular levels, which are specified to each stress condition [3].

Indeed, plants activate a number of defense mechanisms that function to increase tolerance to the adverse conditions imposed by stresses. A major event in response to stresses is the perception and transduction of stress signals through signaling components, which results in the activation of numerous stress-related genes [4]. The products of these genes may participate in the generation of regulatory molecules like the plant hormones ethylene, abscisic acid (ABA), and salicylic acid (SA). These regulatory molecules can, in turn, initiate a second round of signaling that contribute in the final plant response to these abiotic stresses [5].

One of the most important regulatory molecules that are related to environmental responses in plant species is ethylene. As a gaseous plant hormone, ethylene is proved to be involved in plant stress responses, in addition to its roles in germination, fruit ripening, organ abscission, pathogen 
response and senescence, and so forth [6]. Several reports suggested that accumulation of ethylene or its precursor, the ACC (aminocyclopropane-1-carboxylic acid) is exceedingly induced by abiotic stress stimuli such as salinity [7], water stress [8], and flooding [9].

Ethylene function is exerted through modulation of gene expression that was operated in part at transcriptional level by ERF (ethylene response factor) considered as the effectors of ethylene signal. In Arabidopsis, a linear ethylene transduction pathway was proposed, which corresponds to a succession of components from ethylene receptor integrated in the endoplasmic reticulum [10] to transcription factors localized in the nucleus [11].

ERF transcription factors, a huge multigene family of transcription factors regulating the expression of ethylene dependent genes, are the most prominent components directing the specific and diversified plant responses to the ethylene signal. Members of the ERF transcription factor family play important roles in regulating gene expression in response to biotic and abiotic stresses [12]. Ethylene-responsive elementbinding factors (ERFs) form a plant-specific transcriptional factor superfamily of 147 members in Arabidopsis [13]. Interestingly, depending on the circumstances, ERFs can function as both activator and/or repressor elements $[14,15]$. They can also act as an integrative node and common transcription factor of different signalling pathways [16].

ERF proteins are characterized by the presence of highly conserved sequence. This sequence, named ERF domain, provides ERF affinity to the GCC box, comprised in promoter region of ethylene responsive gene. Several studies suggested that ERF proteins have the capacity to specifically bind not only to GCC box, but also to the DRE/CRT motif (found in promoter region of stress responsive genes), known as a cisacting element that responds to cold or osmotic stress $[17,18]$.

Previous studies reported the involvement of many ERF genes in plant environmental stress responses in many plant species, especially in Arabidopsis [19-21]. Tomato (Solanum lycopersicum) is one of the most important agricultural crops and increasing knowledge on their ERF genes involved in abiotic stress responses is a real challenge and can help in plant improvement programs. However, the role of tomato ERFs in response to such stresses remains not enough elucidated.

The present study is the first to examine the expression patterns of the transcription factor gene Sl-ERF.B.3 (formerly called LeERF4) in tomato to determine its regulation in response to a variety of abiotic stress conditions (salinity, drought, flooding, heat, and cold) based on wild type tomato plants. Given that expression pattern of a gene under different conditions can unravel its functionality [22], we used real time RT-PCR approach to study the transcript abundance levels of the studied gene during several abiotic stress responses.

We further focused on Sl-ERF.B.3 role in vegetative growth regulation against salt stress by characterizing two $S l$ ERF.B.3 antisense transgenic tomato lines compared to wild type, and we discussed the Sl-ERF.B.3 role in the layout of shoot and root growth changes related to adaptive responses to salinity. Moreover, we investigated Sl-ERF.B.3 antisense lines tolerance against cold treatment and Sl-ERF.B.3 role on cell membrane injury occurred during low temperature stress responses.

\section{Materials and Methods}

2.1. Plant Material. In the first part of this study, variations on the Sl-ERF.B.3 gene expression under five types of abiotic stresses (salinity, drought, flooding, heat, and cold) were investigated, based on wild type tomato plants (Solanum lycopersicum cv. MicroTom). In the second part of this work we focused on the tomato plant responses to salt and cold stresses. For this purpose, in addition to the investigated wild type tomato, two homozygous independent antisense transgenic tomato lines (Sl-ERF.B.3.AS42 and SlERF.B.3.AS38) (provided by the Laboratory of Genomic and Fruit Biotechnology, UMR990 INRA/INP-ENSA Toulouse, France) were included in this part of our study.

\subsection{The Sl-ERF.B.3 Gene Expression Study}

Growth Conditions. Wild type tomato plants were grown in compost (jiffy pots) under growth chamber conditions $(16 \mathrm{~h}$ light $/ 8 \mathrm{~h}$ darkness, $25^{\circ} \mathrm{C}$ and $80 \%$ humidity); all seedlings were allowed to grow for $21 \mathrm{~d}$ before stress treatment.

Abiotic Stress Treatments. All stress treatments (salinity, drought, flooding, heat, and cold) were applied at the same vegetative growth stage (three-week-old plants). All experiments were repeated three times and each replicate corresponds to six plants. For the drought assay, watering was withheld for $5 \mathrm{~d}$ from plants grown in jiffy pots whose weights were beforehand equilibrated by adding appropriate volume of water to maintain the same soil water levels before drought application. The salt stress was achieved by watering with $250 \mathrm{mM} \mathrm{NaCl}$ solution and shoots harvesting $24 \mathrm{~h}$ later. For the cold stress assay, plants were incubated at $4^{\circ} \mathrm{C}$ for $8 \mathrm{~h}$. To apply heat stress, plants were exposed to $42^{\circ} \mathrm{C}$ for $8 \mathrm{~h}$. The flooding stress was applied by immersing plants (at cotyledon level) in deionised water for $72 \mathrm{~h}$. Immediately following application of each type of stress, the aerial parts were removed and frozen in liquid nitrogen for later use for RNA extraction.

RNA Extraction and cDNA Synthesis. Total RNA was extracted by using an RNeasy RNA Isolation kit (Qiagen, Valencia, CA, USA). Then the RNA was treated with RNasefree DNase (Qiagen, Valencia, CA, USA) at $25^{\circ} \mathrm{C}$ for $1 \mathrm{~h}$. After quantification, two micrograms of total RNA were incubated at $65^{\circ} \mathrm{C}$ for $5 \mathrm{~min}$, then placed for $2 \mathrm{~min}$ on ice, and were used for cDNA synthesis. cDNA was synthesized using Omniscript Reverse Transcriptase enzyme (Qiagen, Valencia, CA, USA) in a total volume of $20 \mu \mathrm{L}$, incubated at $37^{\circ} \mathrm{C}$ for $1 \mathrm{~h}$.

Quantitative Real-Time PCR ( $q R T-P C R)$. Real-time RT-PCR was carried out to determine the expression levels of $S l$ ERF.B.3 (GenBank accession number AY192370) in wild type line under adverse abiotic stress conditions, by using specific primers. qRT-PCR was also performed for Sl-actin51 (Solanum lycopersicum-Actin-51), as endogenous control, 
TABle 1: Primer sequences for expression study.

\begin{tabular}{lcc}
\hline Name & Forward primer $\left(5^{\prime} \rightarrow 3^{\prime}\right)$ & Reverse primer $\left(5^{\prime} \rightarrow 3^{\prime}\right)$ \\
\hline Sl-ERF.B.3 & CGGAGATAAGAGATCCAAGTCGAA & CTTAAACGCTGCACAATCATAAGC \\
Sl-Actin-51 1 - 254 & TGTCCCTATTTACGAGGGTTATGC & CAGTTAAATCACGACCAGCAAGAT \\
ACO -694 & GGCAATTTCATCTGAGTTGTCTGA & CTATTTGATCGATGAAGTTTCTTTTCC \\
Hsp $21-745$ & AAGGGACTCCGCGCTCAT & AGTTGAAGGCCACTCACTTTGTC \\
\hline
\end{tabular}

and for three reference genes: Dehydrin CI7 [23], Hsp21 [24], and ACO1 [25]. The gene-specific primer pairs used for the qRT-PCR are listed in Table 1.

qRT-PCR was performed using cDNA, corresponding to $2 \mathrm{ng}$ of total $\mathrm{RNA}$, in a $10 \mu \mathrm{L}$ reaction volume using SYBR GREEN PCR Master Mix (PE-Applied Biosystems, Foster City, CA, USA), on an ABI PRISM 7900HT sequencedetection system. qRT-PCR conditions were as follows: $50^{\circ} \mathrm{C}$ for $2 \mathrm{~min}, 95^{\circ} \mathrm{C}$ for $10 \mathrm{~min}$, then 40 cycles of $95^{\circ} \mathrm{C}$ for $15 \mathrm{~s}$ and $60^{\circ} \mathrm{C}$ for $1 \mathrm{~min}$, and finally one cycle $95^{\circ} \mathrm{C}$ for $15 \mathrm{~s}$ and $60^{\circ} \mathrm{C}$ for $15 \mathrm{~s}$. For all real-time RT-PCR experiments, each reaction was run in triplicate on 384-well plate. To determine the relative fold difference for each sample in each experiment, we used the comparative $2^{-\Delta \Delta \mathrm{CT}}$ method, where the $\mathrm{Ct}$ (threshold cycle) value for ERF gene was normalized to the Ct value for Sl-Actin-51 (Solanum lycopersicum-Actin-51) and was calculated relative to a calibrator using the formula $2^{-\Delta \Delta \mathrm{CT}}$ (where fold change $=2^{-\Delta \Delta \mathrm{CT}}, \Delta \mathrm{Ct}=\mathrm{Ct}$ (ERF gene) $\mathrm{Ct}(\mathrm{Sl}$-Actin-51), and $\Delta \Delta \mathrm{Ct}=\Delta \mathrm{Ct}$ (stress) $-\Delta \mathrm{Ct}$ (control)).

2.3. Growth Test of Antisense Lines under Salt Stress. Fifty disinfected seeds per line (WT, AS25, and AS38) were placed in Petri dishes on one layer of filter paper, moistened with $15 \mathrm{~mL}$ of sterile water, and incubated at $25^{\circ} \mathrm{C}$ in the dark. Salt treatment was operated by shifting the obtained seedlings into MS (Murashige and Skoog) agar medium supplemented with $\mathrm{NaCl}$ (corresponding to $200 \mathrm{mM}$ concentration). Seven days after, seedlings were transplanted in compost (fertilized at regular intervals by nutrient solution), under growth chamber conditions and watered three times a week by $200 \mathrm{mM} \mathrm{NaCl}$ solution. Growth parameters (stem height, root length, and fresh weight) were assessed after six weeks of salt stress. A mean of four biological repetitions were made.

2.4. Measurement of Electrolyte Leakage in Antisense Lines under Cold Stress. Three-week-old plants from tomato wild type and Sl-ERF.B.3 antisense transgenic lines, grown, in jiffy pot, under optimal conditions, were transferred at $2^{\circ} \mathrm{C}$ for 14 days. After cold exposure, the electrolyte leakage was measured on leaves from both cold treated plants and control plants maintained at $25^{\circ} \mathrm{C}$. Briefly, eight leaf discs were taken from each plant and incubated in $10 \mathrm{~mL}$ of deionized water for three hours under shake at $150 \mathrm{rpm}$ with a horizontal agitator. The electrical conductivities (EC0) of the obtained solutions were determined using a conductivity meter. Then the leaf discs in deionized water were boiled for $15 \mathrm{~min}$. After being thoroughly cooled to room temperature, the conductivities (ECt) of the resulting solutions were determined. The electrolyte leakage was calculated as the ratio of EC0 to ECt. Each data is the average value from three to six independent replicates.

2.5. Data Analysis. Pairwise comparisons were made with Student's $t$-test. For gene expression level data, comparison was made between mRNA level in control sample and that in stress treated sample. For growth parameters and electrolyte leakage data, comparison was made between wild type and antisense transgenic plants under abiotic stress and under control conditions.

Sequence alignments were made using ClustalW tool (default parameters) of MEGA software (version 5.0; http://www.megasoftware.net) [26]. Similar sequences search was executed using the BlastP (Protein Basic Local Alignment Search Tool) tool at the NCBI (http://blast.ncbi.nlm.nih.gov/ Blast.cgi) web site.

\section{Results and Discussion}

3.1. Expression of Tomato Sl-ERF.B.3 Gene under Different Abiotic Stress Treatments. In order to decipher the regulation of tomato Sl-ERF.B.3 gene expression, under the effect of various abiotic stresses, we have performed qRT-PCR approach. This molecular technique allowed us to assess the Sl-ERF.B.3 expression level in wild type (WT) tomato plants treated or not by five types of environmental stress: cold, heat, flooding, drought, and salinity. Figure 1(a) shows characteristic phenotypes of plants which were used for RNA extraction. Compared with control, all treated plants displayed various stress symptoms such as wilting, cotyledon yellowing, and leaf curling. The effectiveness of the abiotic stress treatment was confirmed by the accumulation of the stress reference genes transcripts: Dehydrin CI7 in the salt, drought or cold-treated samples and Hsp21 and ACO in, respectively, heat and flooding treated samples (Figure 1(b)). Relative fold differences in the gene expression levels were calculated by comparing stress treated tomato plants and the corresponding control plants. Our results revealed that $S l$ ERF.B.3 transcripts were highly accumulated in shoots when plants were subjected to heat (20-fold difference), cold (18fold difference), or flooding (1.9-fold difference). However, the Sl-ERF.B.3 mRNA accumulation was twofold lesser when plants were exposed to salinity or drought. This suggests that Sl-ERF.B.3 is really an abiotic-stress-responsive transcription factor, which is upregulated by flooding, cold, or heat, but downregulated by drought or salinity. These environmental stresses contribute to the regulation of Sl-ERF.B.3 expression. 

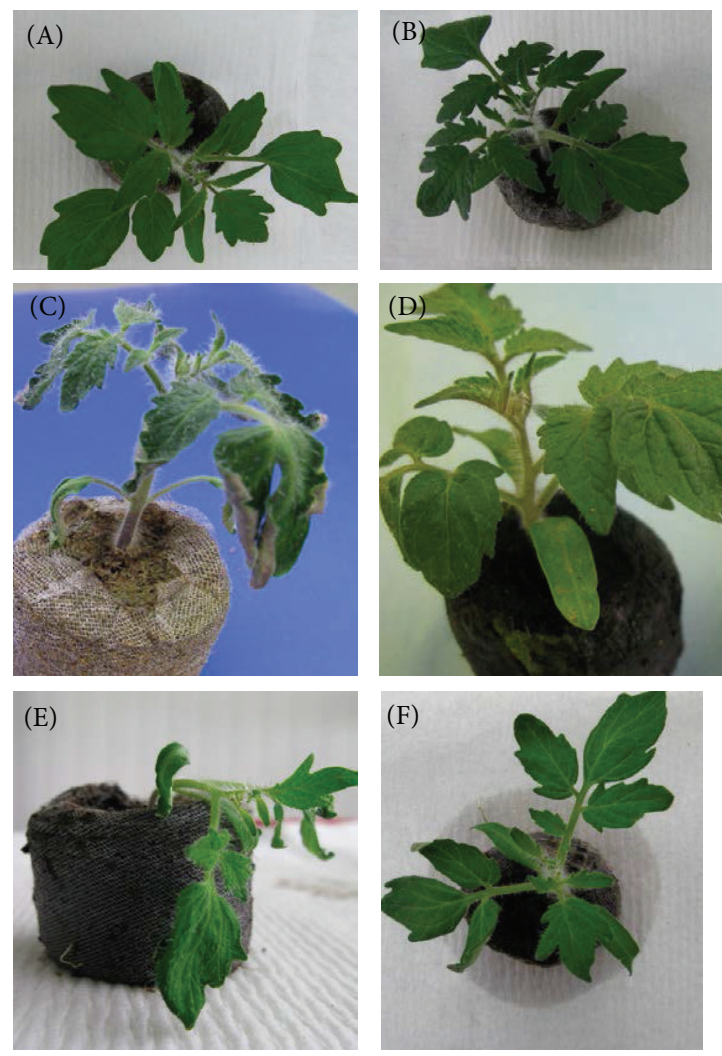

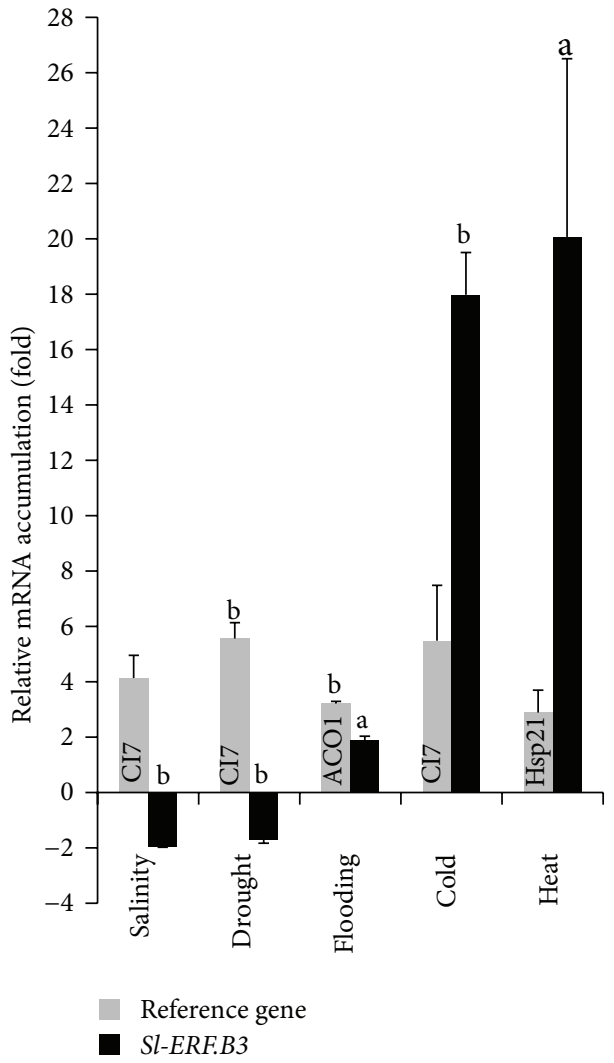

(b)

FIGURE 1: Expression pattern of Sl-ERF.B.3 gene, in aerial parts of wild type tomato plants, in response to five abiotic stresses. Transcripts accumulation was assessed by quantitative real time PCR, as described in material and methods, using total RNA samples extracted from shoots of three weeks old wild type tomato plants: treated by $4^{\circ} \mathrm{C}$ for $8 \mathrm{~h}$ (cold), stored at $42^{\circ} \mathrm{C}$ for $8 \mathrm{~h}$ (heat), watered by $200 \mathrm{mM} \mathrm{NaCl} \mathrm{solution}$ during $24 \mathrm{~h}$ (salinity), watering deprived during $5 \mathrm{~d}$ (drought), or root inundated during $72 \mathrm{~h}$ (flooding). (a) Plants used for RNA extraction refer to those stress treated (by salinity (B); by drought (C); by flooding (D); by cold (E); or by heat (F)) and (A) for no stress-control. For each case one representative plant is presented. (b) The stress treatments effect on Sl-ERF.B.3 and three reference genes (CI7, ACO1, and Hsp21) expression level. The Sl-actin-51 transcripts in the same samples were used as internal control. Data are expressed as relative values, based on the values of control taken as reference sample set to 1.0. Pairwise comparisons were made between control and abiotic stress treated wild-type plants with Student's $t$-test (a: $P<0.05$, b: $P<0.01$ ). Data represent means and standard error of three replications.

Furthermore, it is evident that physiological plant response is critically affected by environmental conditions, and this response is the result of molecular changes, including mostly transcriptional regulators. Such regulators can be common to several environmental stimuli or specific to one kind of stress factor. This leads to support the possibility that Sl-ERF.B.3 is a common regulator of the plant response to many abiotic stress conditions including extreme temperatures, drought, high salinity, and flooding and that it can be a key regulator of plant responses to abiotic stress. It is worth noting that Sl-ERF.B.3/LeERF4 had not previously been reported to be associated with any kind of the predicted abiotic stresses.

The similar trend of regulation of Sl-ERF.B.3, under separately high salinity and drought stress conditions (Figure 1(b)) indicates that Sl-ERF.B.3 seems to be involved in the cross-talk between the plant responses to these stresses.
Probably because both salt and drought stresses lead to common constraints (the water deficit and osmotic stress) [27] and can have a similar stress adaptation mechanism. The fact that different stress adaptation mechanisms share the same regulator suggests its prominent regulator role in the complex stress response network. It was previously shown that salt stress leads to disruption of normal metabolism. In tomato, most of the genes of metabolism were downregulated by salt stress, especially genes related to cell wall metabolism [28]. In this respect, it was demonstrated that upon severe salt stress, this decrease of metabolism was due to water limitation that occurred during drought as well as salt stress. The osmotic stress was caused by the decrease of the soil water potential, which conduced to lowering water availability. This dehydration constraint led to various stress injury at the origin of multiple cellular responses, including changes 
in membrane shape, solute concentration, denaturation of proteins, and production of active oxygen species $[29,30]$.

Given that our results indicate that cold, heat, and at a lesser extent flooding treatments, all separately trigger Sl-ERF.B.3 upregulation in tomato shoots; these three stresses should induce similar stress adaptation mechanisms. Although, high and low temperature stresses are apparently two antagonistic environmental constraints encountered by plants, they lead to similar trend of Sl-ERF.B.3 regulation. This supports the asserting that they have common features and can recruit common molecular response, without being identical [31]. Certainly, at cell level, stress factors such as high and low temperature modify immediately the membrane fluidity by influencing the expression of genes coding plasma membrane proteins $[32,33]$. In this context, it was demonstrated in soybean that various plasma membrane proteins were upregulated under the effect of flooding stress, in order to cope with damages of oxygen lack, mostly proteins related to antioxidative system and heat shock cognate protein [34].

3.2. Transgenic Plants Growth Response to Salt Stress. To study the role of Sl-ERF.B.3 gene in the regulation of tomato vegetative growth under $\mathrm{NaCl}$ stress, we evaluated several growth parameters (stem height, root length, and fresh weight) in $\mathrm{Sl}$ ERF.B.3 antisense transgenic tomato plants and in untransformed WT. Under normal growth conditions, differences in stem growth level were noted between Sl-ERF.B.3 antisense transgenic plants and WT (Figure 2(a)). These transgenic lines displayed slightly better height growth than the untransformed WT (Figure 2(b)), but statistic analysis revealed no significant differences between values. Consequently, the presence of antisense Sl-ERF.B.3 in transgenic plants could not have a significant role in their stem elongation, under normal growth conditions. In tomato, epinasty which is induced by ethylene is a good indicator of salt-sensitivity [35], and ethylene biosynthesis is increased by salt stress [7]. Introducing antisense Sl-ERF.B.3 gene into tomato plants results in less pronounced epinastic phenotype (Figure 2(a)). In transgenic plants, the mRNA of the introduced antisense Sl-ERF.B.3, highly likely binds to target sense mRNA and blocks protein synthesis. Further, the two different antisense lines showed similar phenotype suggesting that it is likely due to the downregulation of Sl-ERF.B.3 gene by introducing its antisense shape. Therefore, Sl-ERF.B.3, acting as activator in the ethylene signal transduction pathway, may be involved in the layout of the epinastic leaf curvature phenotype.

After six weeks of salt stress treatment $(200 \mathrm{mM} \mathrm{NaCl})$, and as seen in Figures 2(b) and 2(c), both WT and transgenic plants exhibited salt related stem growth decrease, which is clearly higher in Sl-ERF.B.3 antisense transgenic lines (significant differences between AS25 and WT). In contrast, the salt stress dependent curved leaf aspect is more pronounced in WT plants (Figure 2(a)). Interestingly, compared with that growing at control conditions, the relative decrease in stem expansion, observed in stressed plants $(200 \mathrm{mM} \mathrm{NaCl})$ is higher in transgenic lines than in WT (Figure 2(c)). Indeed, in response to $200 \mathrm{mM} \mathrm{NaCl}$, more than $36 \%$ of relative stem height reduction was assessed in AS38 transgenic line for only $21.8 \%$ in WT plants. Thus, the long time exposure to salt stress leads to a considerable $\mathrm{NaCl}$ stress dependent stem growth inhibition in tomato plants (whatever the line) (Figures 2(a) and 2(b)) and that the scale of such process is affected by the presence or absence of antisense Sl-ERF.B.3 gene. This inhibition is significantly more enhanced in the presence of antisense Sl-ERF.B.3 (antisense transgenic lines AS25 and AS38) than in its absence (untransformed WT lines) (Figure 2(c)). Considering stem height means, the SlERF.B.3 antisense tomato plants exhibited higher salt stress sensitivity. Consequently, we can emphasize that the presence of antisense Sl-ERF.B.3 and the underexpression of Sl-ERF.B.3 in transgenic plants contribute to the intensification of the $\mathrm{NaCl}$ negative effect on shoot elongation. Salt stress effect on plant growth inhibition is largely documented [36]. One explanation is that salt stress causes unavailable soil water, which leads to water deficit that contributes to stomata closure to minimize water loss, causing $\mathrm{CO}_{2}$ assimilation restriction, which influences adversely plant growth.

As regards to the roots, salt stress application interestingly led to their elongation inhibition in WT but contributed to their stimulation in Sl-ERF.B.3 antisense transgenic lines (Figures 2(d) and 2(e)). This salt stress dependent root elongation improvement reached up to $22 \%$ in AS38 line (Figure 2(e)). Our results clearly emphasize that the presence of tomato antisense Sl-ERF.B.3 allows a significant stimulation of root elongation in response to salt stress. Taking into account the stem growth results, we can emphasize that under salinity and with comparison to WT, transgenic plants exhibited a differentially regulated growth, which is reduced in shoots but stimulated in roots (Figures 2 and 3(a)). Decrease of root to shoot ratio under salt stress was shown in several species as an important adaptive response. Figure 3(b) shows clearly that $200 \mathrm{mM} \mathrm{NaCl}$ slightly affected the WT root to shoot rate (about 0.01 of increase corresponding to $3.5 \%$ ) but induced its increase in AS25 line (about 0.13 of increase corresponding to $35 \%$ ) and, nearly, its multiplication by two in AS38 line (Figure 3(c)).

WT as well as the two Sl-ERF.B.3 antisense transgenic lines displayed total fresh weight reduction, in response to salinity (Figure 4(a)). However, antisense plants were more affected by salt treatment. They displayed more pronounced total fresh weight reduction than that of WT (Figure 4(b)). Considering this growth parameter, salt stressinduced growth reduction is enhanced by the presence of antisense Sl-ERF.B.3 gene. However, the monitoring of $\mathrm{NaCl}$ effect on fresh weight of different plant organs shows a clear discrimination between the aerial parts and roots. In comparison with WT, transgenic lines present the highest salt stress dependent fresh biomass reduction in shoots but the lowest one in roots (Figures 4(c), 4(d), 4(e), and 4(f)). The difference of relative fresh weight reduction values between transformed and untransformed plants reached up to more than $20 \%$ in root, especially for AS38 line (Figure 4(f)). Compared to WT plants, roots of transgenic plants were more protected from growth inhibition, generated by high $\mathrm{NaCl}$ concentration than shoots (Figures 4(d) and 4(f)). Plant growth is considered as coordinated biomass partitioning 

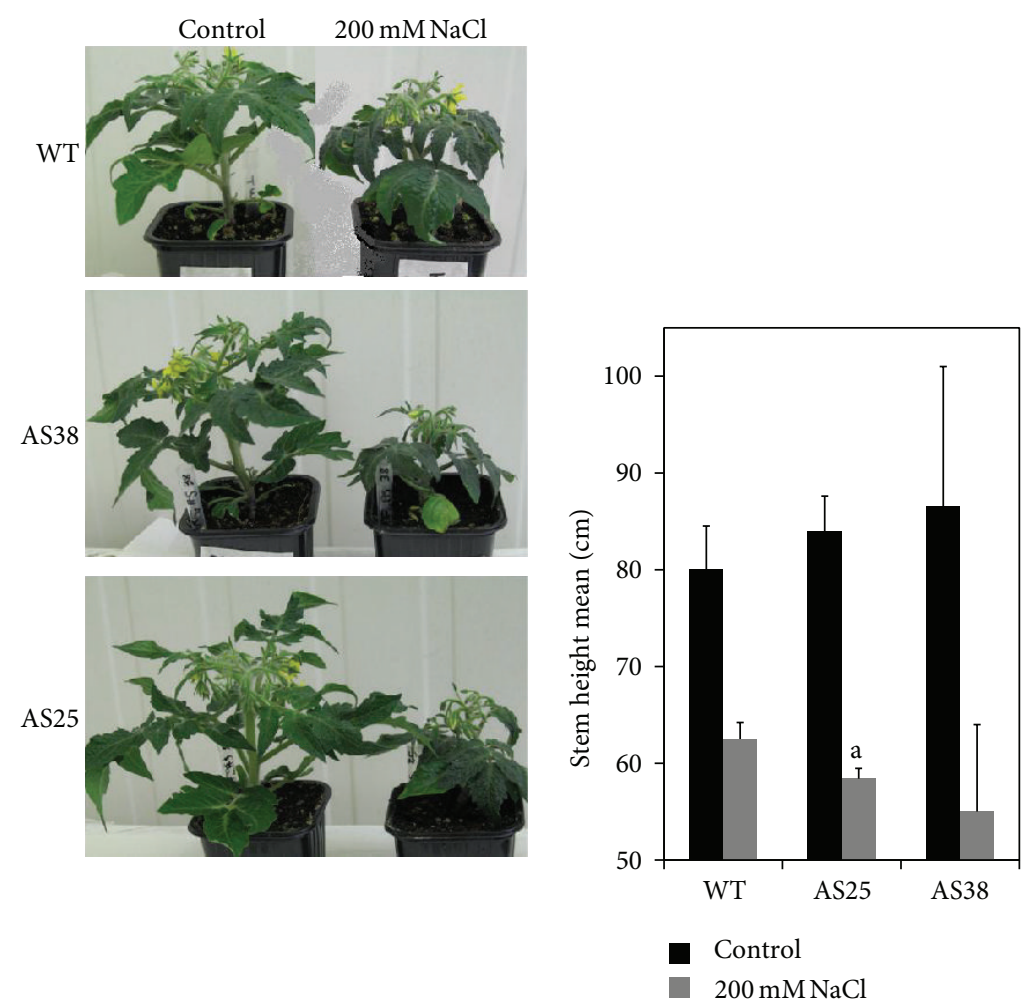

(a)

(b)

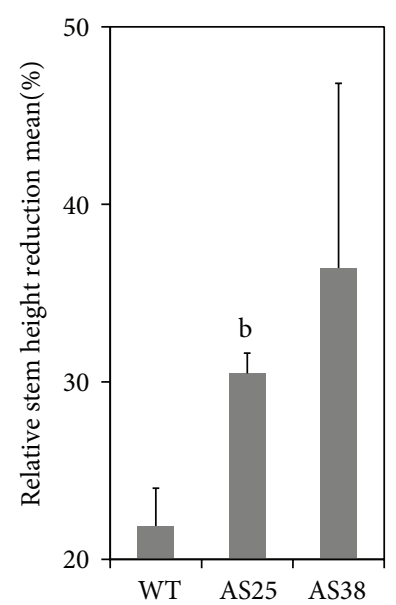

(c)

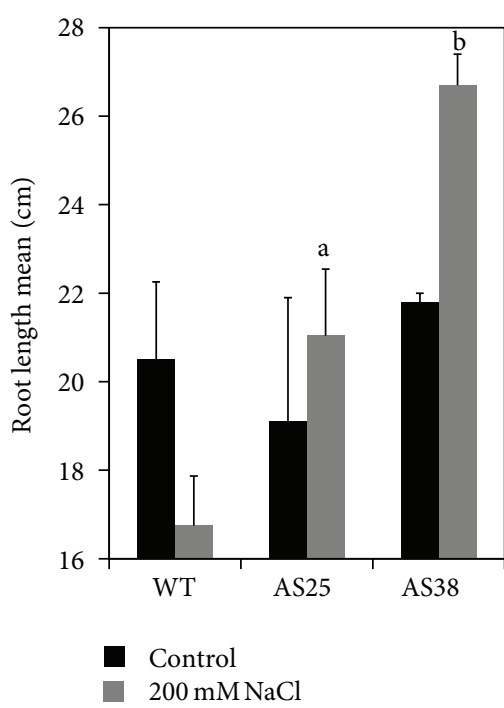

(d)

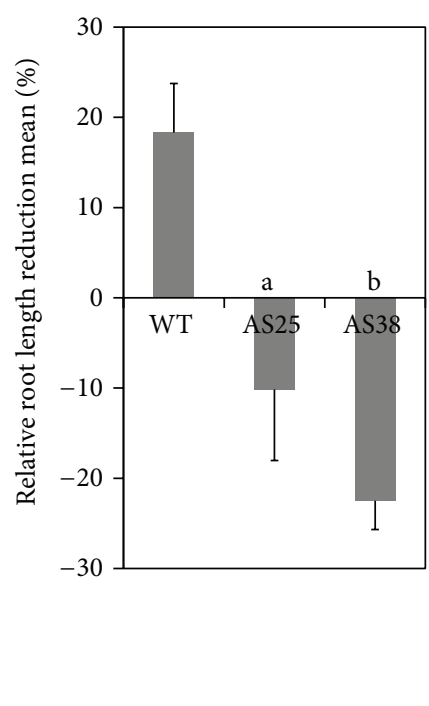

(e)

FIGURE 2: Salt stress effect on wild type and Sl-ERF.B.3 antisense lines growth. (a) Photographs of both Sl-ERF.B.3 antisense transgenic tomato lines (AS38 and AS25) and wild type (WT) were taken at sampling time after six weeks of treatment (irrigation by $200 \mathrm{mM} \mathrm{NaCl} \mathrm{solution).}$ Control: plants were grown under normal growth conditions. Arrows show the leaf epinastic curvature induced by salt stress. Stem height (b) and root length (d) means are assessed in two Sl-ERF.B.3 antisense transgenic tomato lines (AS25 and AS38) and in wild type (WT) grown for six weeks on compost in absence (black bars) or in presence of $\mathrm{NaCl}(200 \mathrm{mM} \mathrm{NaCl})$ (grey bars) in irrigation solution. Percentages of relative reduction in stem height mean (c) and that in root length mean (e) between control $(0 \mathrm{mM} \mathrm{NaCl})$ and salt stressed $(200 \mathrm{mM} \mathrm{NaCl})$ plants of both wild type (WT) and Sl-ERF.B.3 antisense transgenic lines (AS25 and AS38) are presented. Data are means of three replications \pm standard error. Letters indicate significant differences between wild type and transgenic lines according to Student's $t$-test (a: $P<0.05$, b: $P<0.01)$. 


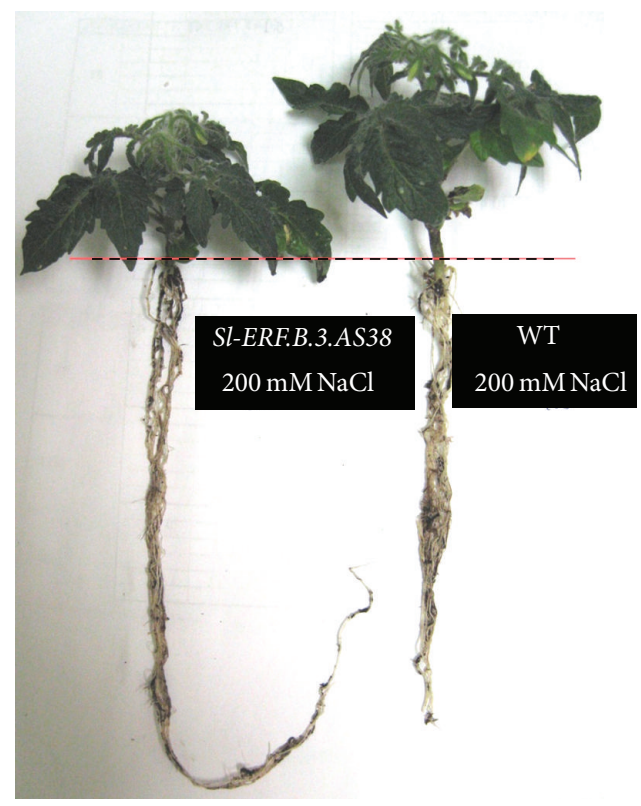

(a)

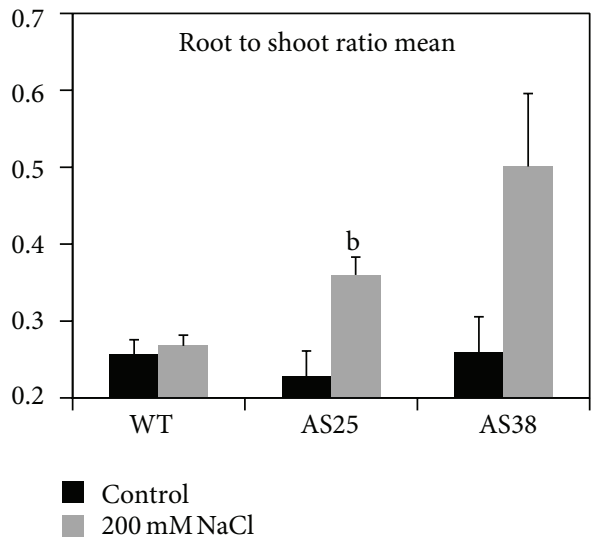

(b)

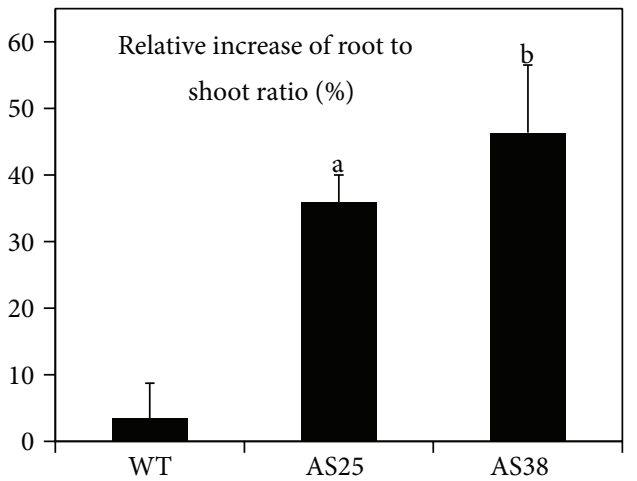

(c)

FIGURE 3: Salt stress effect on root to shoot ratio of Sl-ERF.B.3 antisense transgenic lines (AS25 and AS38) and wild type (WT) tomato plants. (a) Photograph, taken at sampling time after six weeks of salt stress (regular irrigation by $200 \mathrm{mM} \mathrm{NaCl}$ solution), shows growth differences between wild type (WT) and Sl-ERF.B.3-antisense transgenic line (AS38). (b) Variation of root to shoot ratio mean under salt treatment $(200 \mathrm{mM} \mathrm{NaCl})$. (c) Relative increase rate of root to shoot ratio in response to sever salt stress treatment in wild type (WT) and Sl-ERF.B.3 antisense transgenic lines (AS25 and AS38). Pairwise comparisons were made between wild type plants and antisense transgenic plants with Student's $t$-test (a: $P<0.05$, b: $P<0.01$ ). Data represent means and standard error of three replications.

responses between shoots and roots. Growth of the shoot is more sensitive to salt stress than root growth [37]. Given that salinity results in the establishment of water deficit stress, longer root system should facilitate water absorption from deeper soil horizons and biomass increase. The differential response to salinity in both shoot and root is accompanied by differential changes in roots and shoots hormone concentrations. In particular, the inhibition of shoot growth in favor of a shift in biomass allocation to the root may be explained by a differential auxin to cytokinin ratio [37]. Root to shoot ratio is usually increased under salinity [38]. Root is the first plant organ encountering soil salinity, so the early salt stress response is first triggered in roots. In particular, after only 15 min of treatment, alteration of gene expression can be noted in roots, in particular, early response genes including transcriptional activators [39]. In this report we demonstrate that Sl-ERF.B.3 is involved in the regulation of this adaptive response to salinity, because, in Sl-ERF.B.3 antisense lines, shoots growth is much more sensitive to salt treatment than roots growth. Furthermore, it has been shown recently that root ethylene production is inhibited by salt treatment [40], because ethylene has an inhibitor role in root growth [37, 41]. The ethylene decrease in roots may protect roots from its growth inhibitor effect. For a large variety of plants, root growth is often less sensitive to salt stress than is growth of the shoot [42], including tomato plants [35]. 


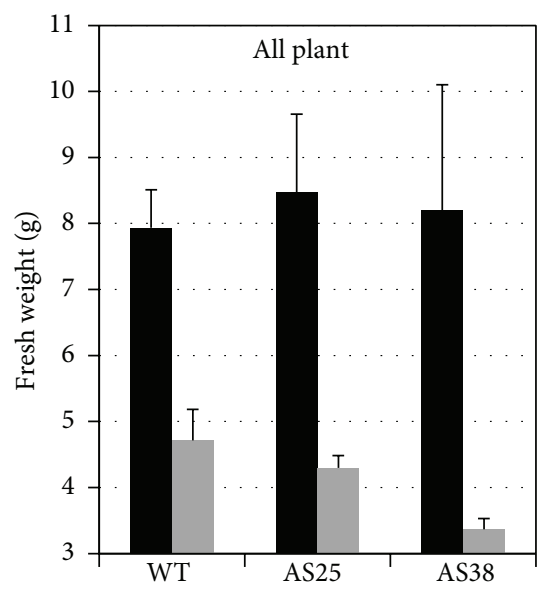

(a)

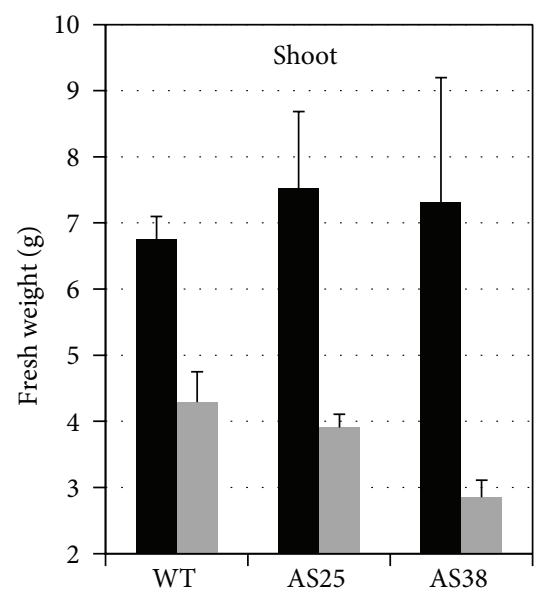

(c)

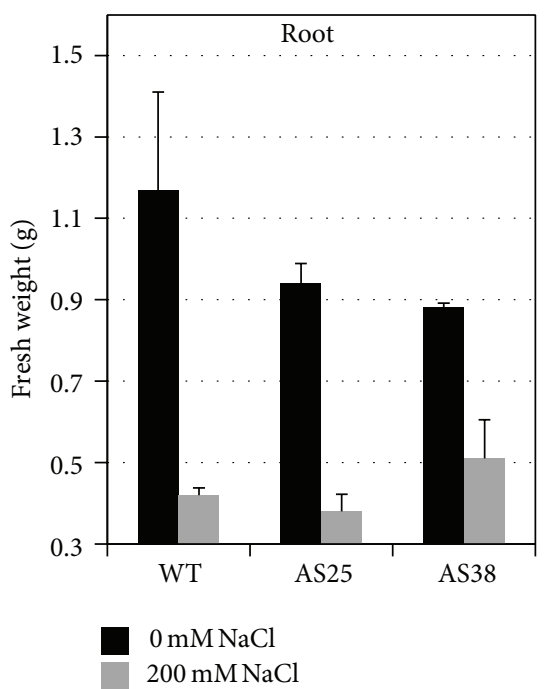

(e)

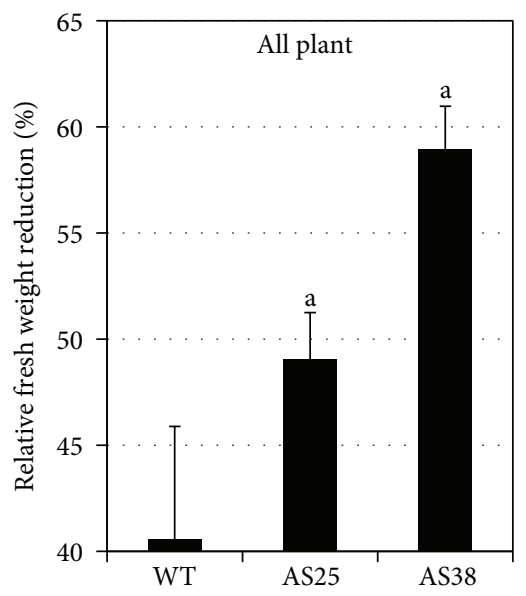

(b)

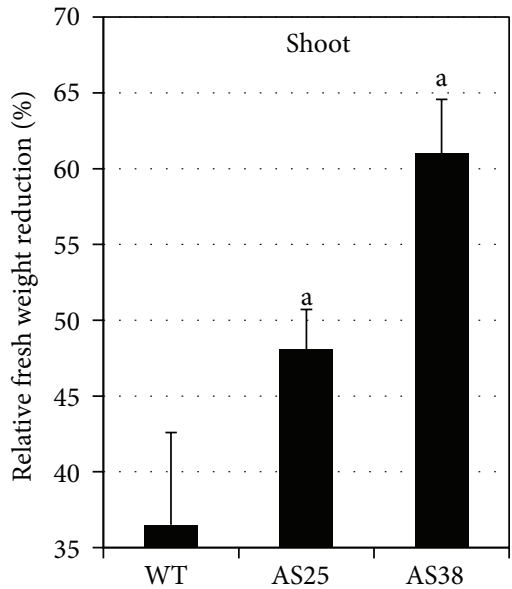

(d)

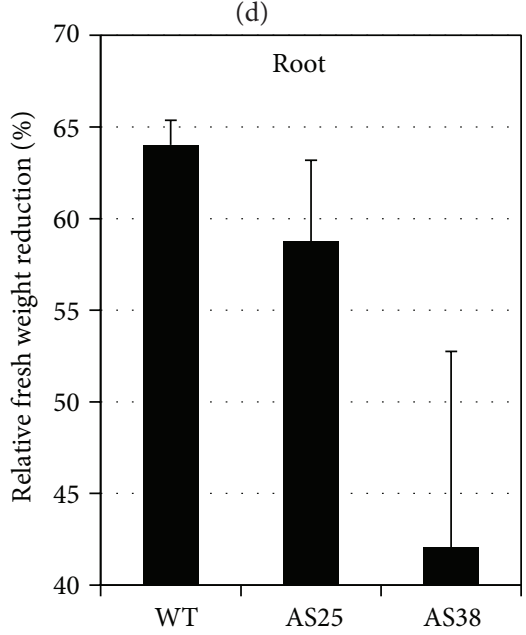

(f)

FIGURE 4: Salt stress effect on fresh biomass accumulation of Sl-ERF.B.3 antisense transgenic lines (AS25 and AS38) and wild type (WT) tomato plants. Variation of fresh weight means under salt treatment $(200 \mathrm{mM} \mathrm{NaCl})$ and in control conditions $(0 \mathrm{mM} \mathrm{NaCl})$, in whole plants (a), in shoots (c), and in roots (e). Salt stress effect on relative fresh weight reduction is assessed in whole plants (b), in shoots (d), and in roots (f). Pairwise comparisons were made between wild type and transgenic plants with Student's $t$-test (a: $P<0.05$, b: $P<0.01$ ). Data represent means and standard error of three replications. 

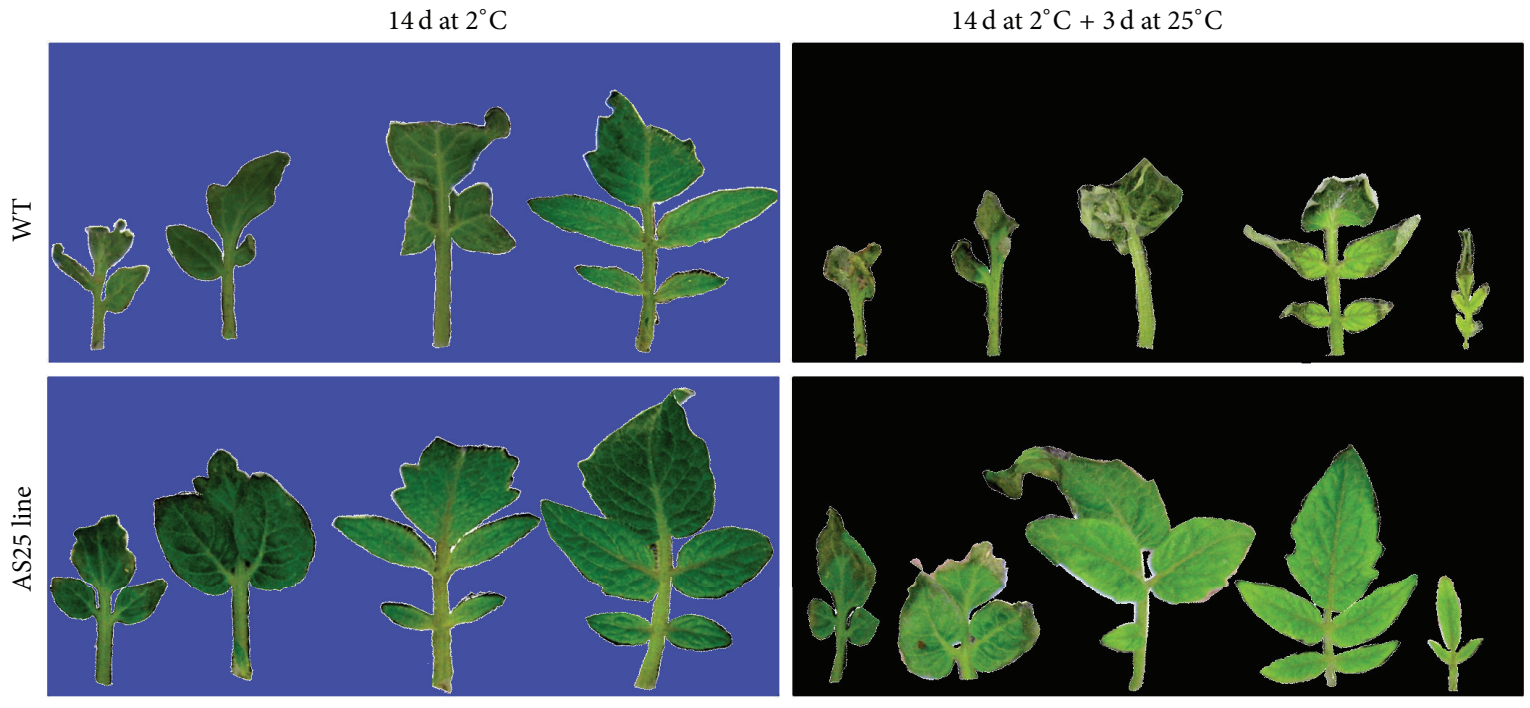

(a)

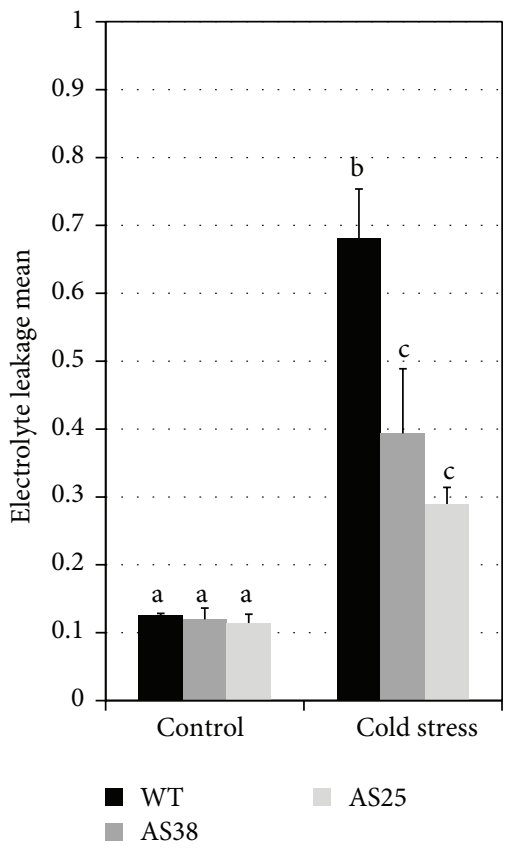

(b)

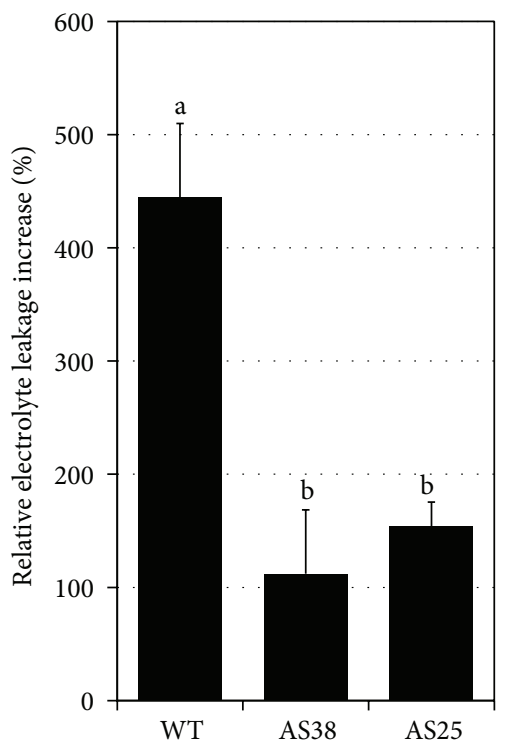

FIgURE 5: Cold stress effect on wild type and Sl-ERF.B.3 antisense lines. (a) Photographs of both Sl-ERF.B.3 antisense transgenic tomato lines (AS25) and wild type (WT) were taken after 14 days of cold treatment $\left(2^{\circ} \mathrm{C}\right)$ then three days of recovery $\left(25^{\circ} \mathrm{C}\right)$. Control: plants were grown under normal growth conditions. (b) Electrolyte leakage means are assessed in two Sl-ERF.B.3 antisense transgenic tomato lines (AS25 and AS38) and in wild type (WT) treated or nontreated by incubation at $2^{\circ} \mathrm{C}$ temperature during 14 days. (c) Percentages of relative increase in electrolyte leakage between control (maintained at $25^{\circ} \mathrm{C}$ ) and cold stressed (incubated at $2^{\circ} \mathrm{C}$ ) plants of both wild type (WT) and Sl-ERF.B.3 antisense transgenic lines (AS25 and AS38). Data are means of three replicates \pm standard error. Same letters and different letters indicate, respectively, nonsignificant differences and significant differences between data, according to Student's $t$-test.

3.3. Transgenic Plants Response to Cold Stress. Response to cold stress was investigated in both WT and Sl-ERF.B.3 transgenic plants, which exhibited different degrees of stress injury (Figure 5(a)). Tomato, a plant native to warm habitats, displays symptoms of injury upon low temperature exposure
[43]. Ion leakage was measured to reflect the level of cellular damages after $14 \mathrm{~d}$ of cold treatment. Statistic analysis showed no significant differences between electrolyte leakage values assessed on all nonstressed plant tissues, whatever the line (Figure 5(b)). However, cold stress treatment data revealed 


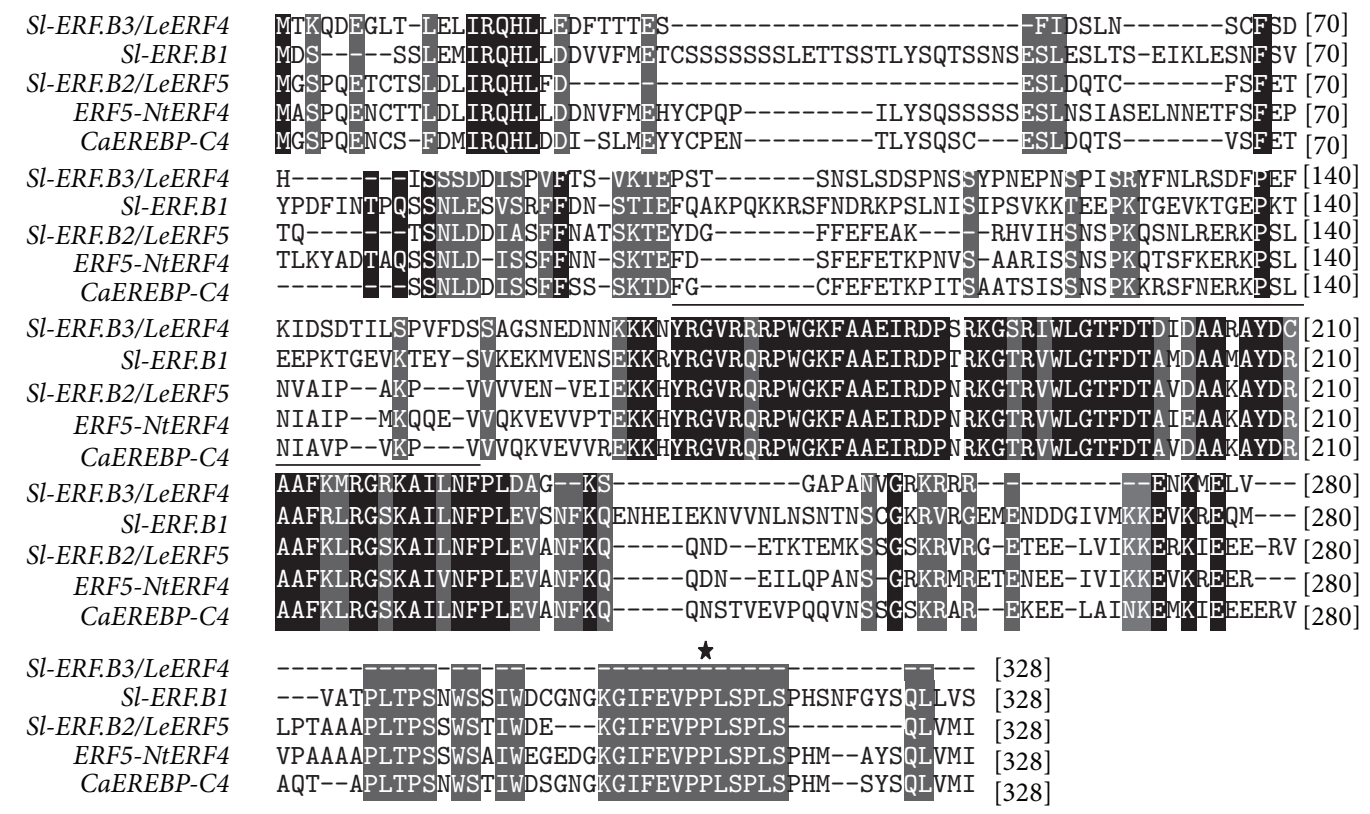

FIGURE 6: Multiple amino acid sequence alignment of tomato Sl-ERF.B.3 with related amino acid sequences of tomato Sl-ERF.B.1, tomato SlERF.B.2, Capsicum annuum CaEREBP-C4 (AAX20037.1), and Nicotiana tabacum NtERF4/ERF5 (Q40478.1). Conserved residues are shaded in black. Dark grey shading indicates similar residues in four out of five of the sequences. Alignments were made in ClustalW using the default parameters. The black bar above the sequences represents the ERF domain. Star represents putative MAP kinase phosphorylation site absent in Sl-ERF.B.3 sequence. Dashes show gaps in the amino acid sequences introduced to optimize alignment. Numbers show the positions of amino acid residues.

significant differences between WT and transgenic lines (Figures 5(b) and 5(c)). Results, presented in Figure 5(b) showed that cold treatment leads to a strong increase in ion leakage in WT leaves tissue, reaching up 0.68 , for only 0.28 and 0.39, respectively, in AS25 and AS38 Sl-ERF.B.3 antisense lines. This indicates that Sl-ERF.B.3 antisense transgenic lines are able to maintain significantly, low percentage of electrolyte leakage increase in their leaf tissues, compared with WT and they are clearly more tolerant to cold stress. Thus, introducing antisense Sl-ERF.B.3 into tomato plants may confer reduced plasma membrane injury and enhanced tolerance against low temperature stress. This conclusion is supported by the improvement of cold tolerance in the two independent transgenic lines expressing antisense $S l$ ERF.B.3, with statistically no significant differences between measurements. Therefore, Sl-ERF.B.3 is a cold stress related gene, which may act as component of the cold stress response pathway in tomato, playing a role in the layout of cold stress symptoms. Recent study reported that the overexpression of an ERF transcription factor, TaPIE1 in wheat reduces the plasma membrane damages, contributing to enhanced resistance to freezing, by upregulating a range of stressrelated genes, downstream the ethylene signaling pathway [44].

3.4. Sl-ERF.B.3 Sequence Study. To search for potential structural similarities between Sl-ERF.B.3 and stress-involved proteins, we performed BLAST search using amino acid sequence of Sl-ERF.B.3 and multiple amino-acid sequence alignment using formerly characterized stress related proteins. Data indicated that in addition to subclass B members (Sl-ERF.B.1, Sl-ERF.B.2), Sl-ERF.B.3 exhibited sequence similarities with others ERF proteins that previous reports highlighted their involvement in plant stress responses, CaEREBP-C4 and ERF5/NtERF4. CaEREBP-C4 is a pepper transcription factor shown to be involved in cold stress responses [45], while ERF5/NtERF4 was reported to be a transcriptional activator [46], involved in the early plant responses to wounding [47]. Until now, Sl-ERF.B.3/LeERF4 has been only characterized as strongly induced against wounding stress [48]. In this study we demonstrated its involvement in tomato response to other abiotic stresses, including heat and cold stresses. At the perception level, both stresses affect the same site of temperature perception, the plasma membrane, but they trigger opposite changes in its fluidity, leading to the activation of different MAPK (mitogen-activated protein kinase) cascades [49]. Results, in Figure 6 show that Sl-ERF.B.3 amino acid sequence lacks the putative MAP kinase phosphorylation site, found in Cterminal region of the two other members of subclass $B$ and both of that of NtERF4 and CaEREBP-C4. However, Sl-ERF.B.3 includes in its amino acid sequence an acidic domain [48], which had been shown in other species to act as activation domain [50]. Considering the overall results, we can assert that Sl-ERF.B.3 is a transcriptional activator that may probably be negatively involved in salt stress dependent growth regulation and in cold stress response. 
Further research should address this issue and allow better understanding of Sl-ERF.B.3 role in cold and salt stress responses.

\section{Conflict of Interests}

The authors declare that there is no conflict of interests regarding the publication of this paper.

\section{References}

[1] J. L. Araus, G. A. Slafer, M. P. Reynolds, and C. Royo, "Plant breeding and drought in C3 cereals: what should we breed for?" Annals of Botany, vol. 89, no. 7, pp. 925-940, 2002.

[2] E. A. Bray, J. Bailey-Serres, and E. Weretilnyk, "Responses to abiotic stresses," in Biochemistry and Molecular Biology of Plants, W. Gruissem, B. Buchannan, and R. Jones, Eds., pp. 158-1249, American Society of Plant Biologists, Rockville, Md, USA, 2000.

[3] M. Cheng, P. Liao, W. Kuo, and T. Lin, "The arabidopsis ethylene response factorl regulates abiotic stress-responsive gene expression by binding to different cis-acting elements in response to different stress signals," Plant Physiology, vol. 162, no. 3, pp. 1566-1582, 2013.

[4] K. Shinozaki and K. Yamaguchi-Shinozaki, "Gene networks involved in drought stress response and tolerance," Journal of Experimental Botany, vol. 58, no. 2, pp. 221-227, 2007.

[5] L. Xiong, K. S. Schumaker, and J. K. Zhu, "Cell signaling during cold, drought, and salt stress," Plant Cell, vol. 14, pp. S165-S183, 2002.

[6] Y. Chen, N. Etheridge, and G. E. Schaller, "Ethylene signal transduction," Annals of Botany, vol. 95, no. 6, pp. 901-915, 2005.

[7] P. J. Zapata, M. Á. Botella, M. T. Pretel, and M. Serrano, "Responses of ethylene biosynthesis to saline stress in seedlings of eight plant species," Plant Growth Regulation, vol. 53, no. 2, pp. 97-106, 2007.

[8] I. Narayana, S. Lalonde, and H. S. Saini, "Water-stress-induced ethylene production in wheat: a fact or artifact?" Plant Physiology, vol. 96, no. 2, pp. 406-410, 1991.

[9] K. J. Bradford and S. F. Yang, "Stress-induced ethylene production in the ethylene-requiring tomato mutant diageotropica," Plant Physiology, vol. 65, pp. 327-330, 1980.

[10] Y. F. Chen, N. E. Etheridge, and G. E. Schaller, "Ethylene signal transduction," Annals of Botany, vol. 95, no. 6, pp. 901-915, 2005.

[11] H. Guo and J. R. Ecker, "The ethylene signaling pathway: new insights," Current Opinion in Plant Biology, vol. 7, no. 1, pp. 4049, 2004.

[12] G. Zhang, M. Chen, X. Chen et al., "Phylogeny, gene structures, and expression patterns of the ERF gene family in soybean (Glycine max L.)," Journal of Experimental Botany, vol. 59, no. 15, pp. 4095-4107, 2008.

[13] T. Nakano, K. Suzuki, T. Fujimura, and H. Shinshi, "Genomewide analysis of the ERF gene family in arabidopsis and rice," Plant Physiology, vol. 140, no. 2, pp. 411-432, 2006.

[14] S. Y. Fujimoto, M. Ohta, A. Usui, H. Shinshi, and M. OhmeTakagi, "Arabidopsis ethylene-responsive element binding factors act as transcriptional activators or repressors of GCC boxmediated gene expression," Plant Cell, vol. 12, no. 3, pp. 393-404, 2000.

[15] H. Zhang, Z. Huang, B. Xie et al., "The ethylene-, jasmonate-, abscisic acid- and NaCl-responsive tomato transcription factor
JERF1 modulates expression of GCC box-containing genes and salt tolerance in tobacco," Planta, vol. 220, no. 2, pp. 262-270, 2004.

[16] L. Oñate-Sánchez and K. B. Singh, "Identification of arabidopsis ethylene-responsive element binding factors with distinct induction kinetics after pathogen infection," Plant Physiology, vol. 128, no. 4, pp. 1313-1322, 2002.

[17] J. Lee, J. Hong, S. Oh, S. Lee, D. Choi, and T. K. Woo, “The ethylene-responsive factor like protein 1 (CaERFLP1) of hot pepper (Capsicum annuum L.) interacts in vitro with both GCC and DRE/CRT sequences with different binding affinities: Possible biological roles of CaERFLP1 in response to pathogen infection and high salinity conditions in transgenic tobacco plants," Plant Molecular Biology, vol. 55, no. 1, pp. 61-81, 2004.

[18] H. Wang, Z. Huang, Q. Chen et al., "Ectopic overexpression of tomato JERF3 in tobacco activates downstream gene expression and enhances salt tolerance," Plant Molecular Biology, vol. 55, no. 2, pp. 183-192, 2004.

[19] R. C. Lin, H. J. Park, and H. Y. Wang, "Role of Arabidopsis RAP2.4 in regulating lightand ethylene-mediated developmental processes and drought stress tolerance," Molecular Plant, vol. 1, no. 1, pp. 42-57, 2008.

[20] H. Y. Park, H. Y. Seok, D. H. Woo et al., "AtERF71/HRE2 transcription factor mediates osmotic stress response as well as hypoxia response in Arabidopsis," Biochemical and Biophysical Research Communications, vol. 414, no. 1, pp. 135-141, 2011.

[21] C. Yang, F. Hsu, J. Li, N. Wang, and M. Shih, "The AP2/ERF transcription factor AtERF73/HRE1 modulates ethylene responses during hypoxia in Arabidopsis," Plant Physiology, vol. 156, no. 1, pp. 202-212, 2011.

[22] A. Singh, A. Pandey, V. Baranwal, S. Kapoor, and G. K. Pandey, "Comprehensive expression analysis of rice phospholipase D gene family during abiotic stresses and development.", Plant signaling \& behavior, vol. 7, no. 7, pp. 847-855, 2012.

[23] H. H. Kirch, J. van Berkel, H. Glaczinski, F. Salamini, and C. Gebhardt, "Structural organization, expression and promoter activity of a cold-stress-inducible gene of potato (Solanum tuberosum L.)," Plant Molecular Biology, vol. 33, no. 5, pp. 897909, 1997.

[24] I. Neta-Sharir, T. Isaacson, S. Lurie, and D. Weiss, "Dual role for tomato heat shock protein 21: protecting photosystem II from oxidative stress and promoting color changes during fruit maturation," The Plant Cell, vol. 17, no. 6, pp. 1829-1838, 2005.

[25] X. Nie, R. P. Singh, and G. C. C. Tai, "Molecular characterization and expression analysis of 1-aminocyclopropane-1carboxylate oxidase homologs from potato under abiotic and biotic stresses," Genome, vol. 45, no. 5, pp. 905-913, 2002.

[26] K. Tamura, D. Peterson, N. Peterson, G. Stecher, M. Nei, and S. Kumar, "MEGA5: molecular evolutionary genetics analysis using maximum likelihood, evolutionary distance, and maximum parsimony methods," Molecular Biology and Evolution, vol. 28, no. 10, pp. 2731-2739, 2011.

[27] J. Zhu, "Salt and drought stress signal transduction in plants," Annual Review of Plant Biology, vol. 53, pp. 247-273, 2002.

[28] B. Ouyang, T. Yang, H. Li et al., "Identification of early salt stress response genes in tomato root by suppression subtractive hybridization and microarray analysis," Journal of Experimental Botany, vol. 58, no. 3, pp. 507-520, 2007.

[29] E. A. Bray, "Plant responses to water deficit," Trends in Plant Science, vol. 2, no. 2, pp. 48-54, 1997.

[30] J. Dat, S. Vandenabeele, E. Vranová, M. van Montagu, D. Inzé, and F. van Breusegem, "Dual action of the active oxygen 
species during plant stress responses," Cellular and Molecular Life Sciences, vol. 57, no. 5, pp. 779-795, 2000.

[31] C. Guy, "Molecular responses of plants to cold shock and cold acclimation," Journal of Molecular Microbiology and Biotechnology, vol. 1, no. 2, pp. 231-242, 1999.

[32] I. Horvath, A. Glatz, V. Varvasovszki et al., "Membrane physical state controls the signaling mechanism of the heat shock response in Synechocystis PCC 6803: identification of hsp17 as a "fluidity gene'," Proceedings of the National Academy of Sciences of the United States of America, vol. 95, no. 7, pp. 3513-3518, 1998.

[33] B. L. Örvar, V. Sangwan, F. Omann, and R. S. Dhindsa, "Early steps in cold sensing by plant cells: the role of actin cytoskeleton and membrane fluidity," The Plant Journal, vol. 23, no. 6, pp. 785-794, 2000.

[34] S. Komatsu, T. Wada, Y. Abaléa et al., "Analysis of plasma membrane proteome in soybean and application to flooding stress response," Journal of Proteome Research, vol. 8, no. 10, pp. 4487-4499, 2009.

[35] R. A. Jones and A. S. El-Beltagy, "Epinasty promoted by salinity or ethylene is an indicator of salt-sensitivity in tomatoes," Plant Cell and Environment, vol. 12, no. 8, pp. 813-817, 1989.

[36] R. Munns, "Physiological processes limiting plant growth in saline soils: some dogmas and hypotheses," Plant, Cell \& Environment, vol. 16, no. 1, pp. 15-24, 1993.

[37] A. Albacete, M. E. Ghanem, C. Martínez-Andújar et al., "Hormonal changes in relation to biomass partitioning and shoot growth impairment in salinized tomato (Solanum lycopersicum L.) plants," Journal of Experimental Botany, vol. 59, no. 15, pp. 4119-4131, 2008.

[38] R. W. Weinberg, H. R. Lerner, and A. Poljakoff-Mayber, "Changes in growth and water-soluble solute concentrations in Sorghum bicolor stressed with sodium and potassium salts," Physiologia Plantarum, vol. 62, pp. 472-480, 1984.

[39] S. Kawasaki, C. Borchert, M. Deyholos et al., "Gene expression profiles during the initial phase of salt stress in rice," The Plant Cell, vol. 13, no. 4, pp. 889-905, 2001.

[40] L. Karni, H. Aktas, G. Deveturero, and B. Aloni, "Involvement of root ethylene and oxidative stress-related activities in preconditioning of tomato transplants by increased salinity," Journal of Horticultural Science and Biotechnology, vol. 85, no. 1, pp. 23-29, 2010.

[41] E. Sergeeva, S. Shah, and B. R. Glick, "Growth of transgenic canola (Brassica napus cv. Westar) expressing a bacterial 1aminocyclopropane-1-carboxylate (ACC) deaminase gene on high concentrations of salt," World Journal of Microbiology and Biotechnology, vol. 22, no. 3, pp. 277-282, 2006.

[42] J. M. Cheeseman, "Mechanisms of salinity tolerance in plants," Journal of Plant Physiology, vol. 87, pp. 547-550, 1988.

[43] M. E. Saltveit and L. Morris, "Chilling injury of horticultural crops," in Overview Chilling Injury of Horticultural Crops, C. Y. Wang, Ed., pp. 3-15, CRC Press, Boca Raton, Fla, USA, 1990.

[44] X. Zhu, L. Qi, X. Liu et al., "The wheat ethylene response factor transcription factor pathogen-induced ERF1 mediates host responses to both the necrotrophic pathogen Rhizoctonia cerealis and freezing stresses," Plant Physiology, vol. 164, no. 3, pp. 1499-1514, 2014.

[45] H. B. Kwon, E. W. Hwang, and J. J. Cheong, "Transgenic expression of an ethylene responsive element binding cProtein of capsicum annuum (CaEREBP-C4) in tobacco confers cold tolerance," Journal of the Korean Society of Applied Biological Chemistry, vol. 52, no. 5, pp. 405-411, 2009.
[46] M. Ohta, M. Ohme-Takagi, and H. Shinshi, "Three ethyleneresponsive transcription factors in tobacco with distinct transactivation functions," Plant Journal, vol. 22, no. 1, pp. 29-38, 2000.

[47] K. S. Suzuki, N. S. Suzuki, M. O. Ohme-Takagi, and H. Shinshi, "Immediate early induction of mRNAs for ethylene-responsive transcription factors in tobacco leaf strips after cutting," The Plant Journal, vol. 15, no. 5, pp. 657-665, 1998.

[48] B. Tournier, M. T. Sanchez-Ballesta, B. Jones et al., "New members of the tomato ERF family show specific expression pattern and diverse DNA-binding capacity to the GCC box element," FEBS Letters, vol. 550, no. 1-3, pp. 149-154, 2003.

[49] V. Sangwan, B. L. Örvar, J. Beyerly, H. Hirt, and S. Dhindsa Rajinder, "Opposite changes in membrane fluidity mimic cold and heat stress activation of distinct plant MAP kinase pathways," Plant Journal, vol. 31, no. 5, pp. 629-638, 2002.

[50] H. Yang, H. Shen, L. Chen et al., "The OsEBP-89 gene of rice encodes a putative EREBP transcription factor and is temporally expressed in developing endosperm and intercalary meristem," Plant Molecular Biology, vol. 50, no. 3, pp. 379-391, 2002. 

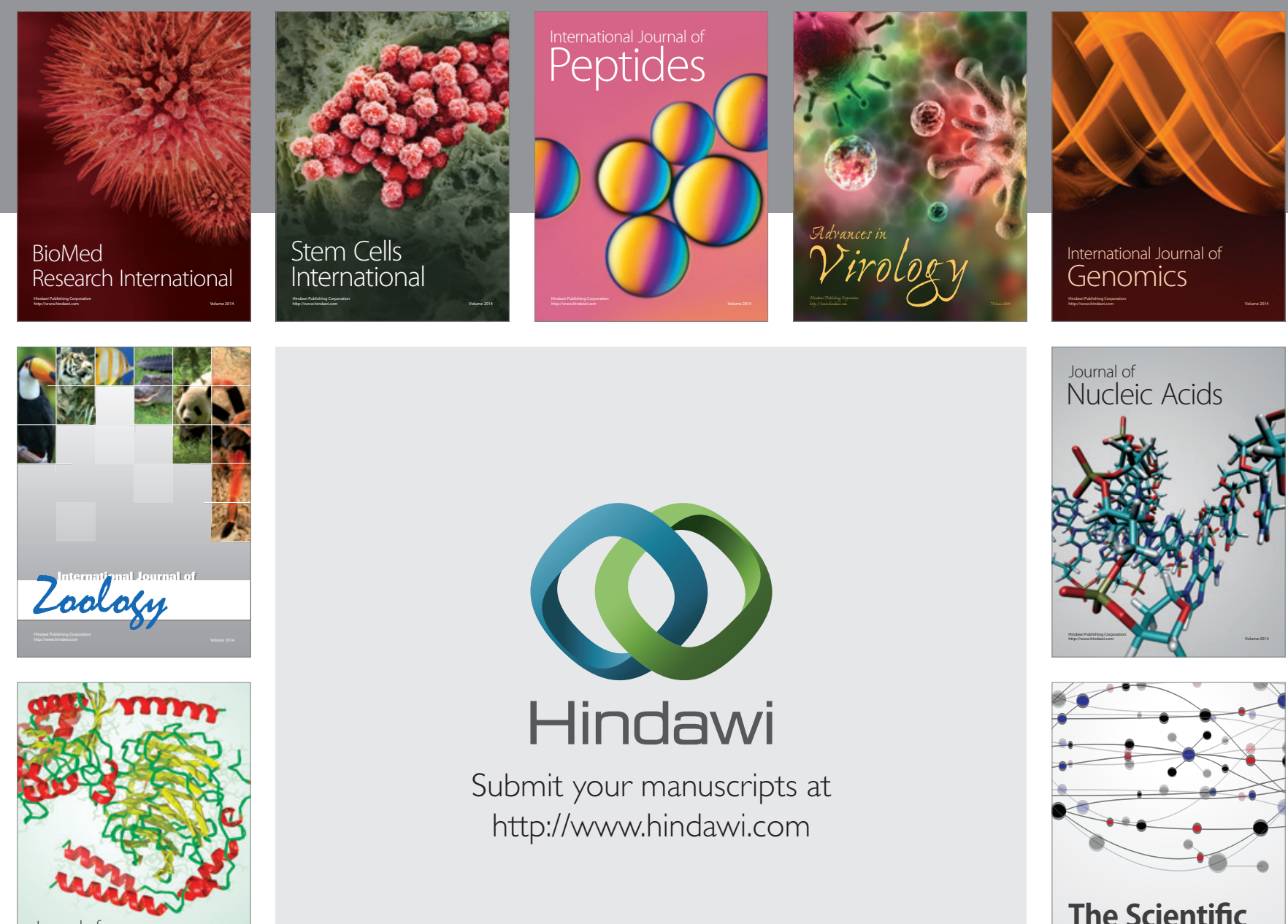

Submit your manuscripts at

http://www.hindawi.com

Journal of
Signal Transduction
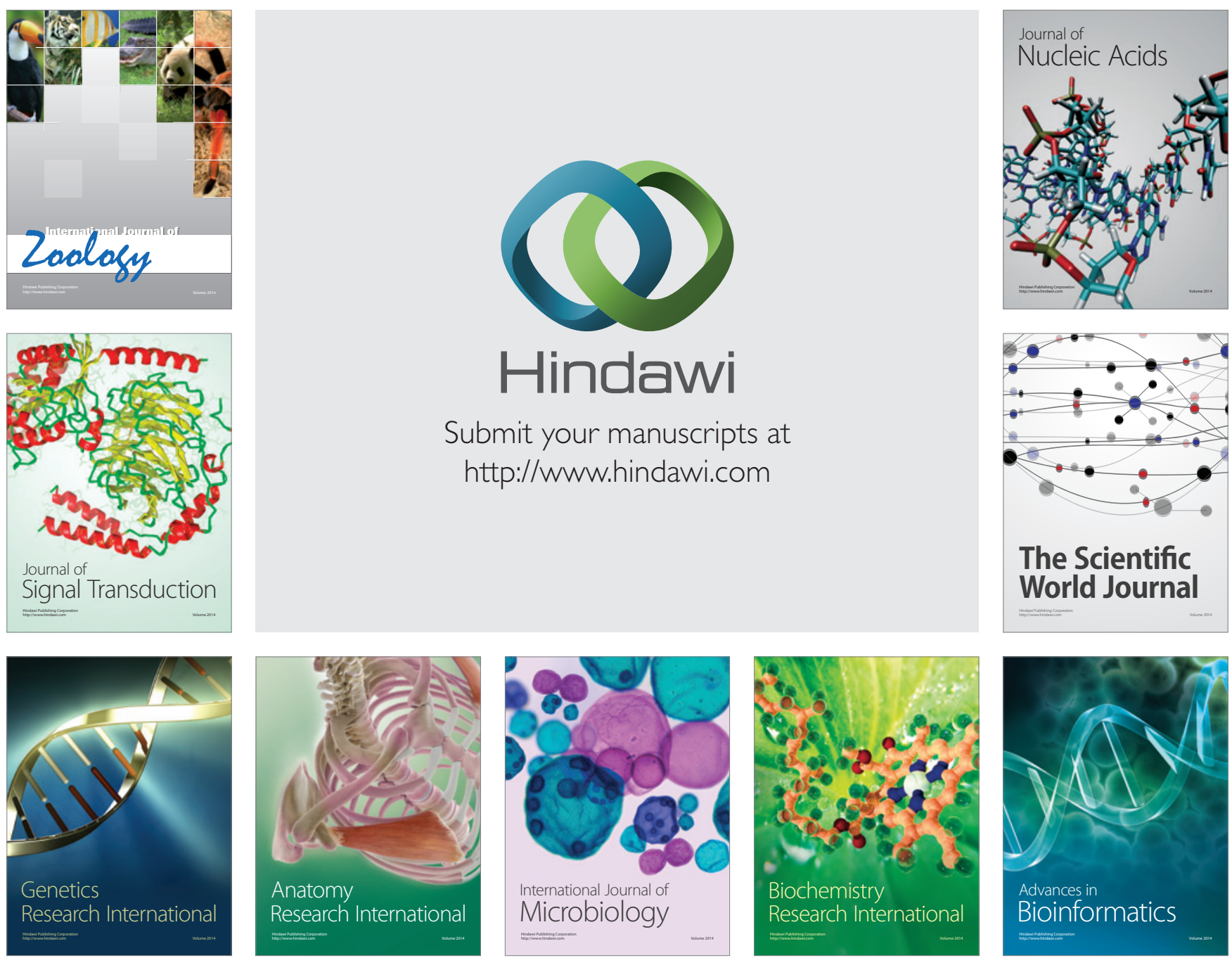

The Scientific World Journal
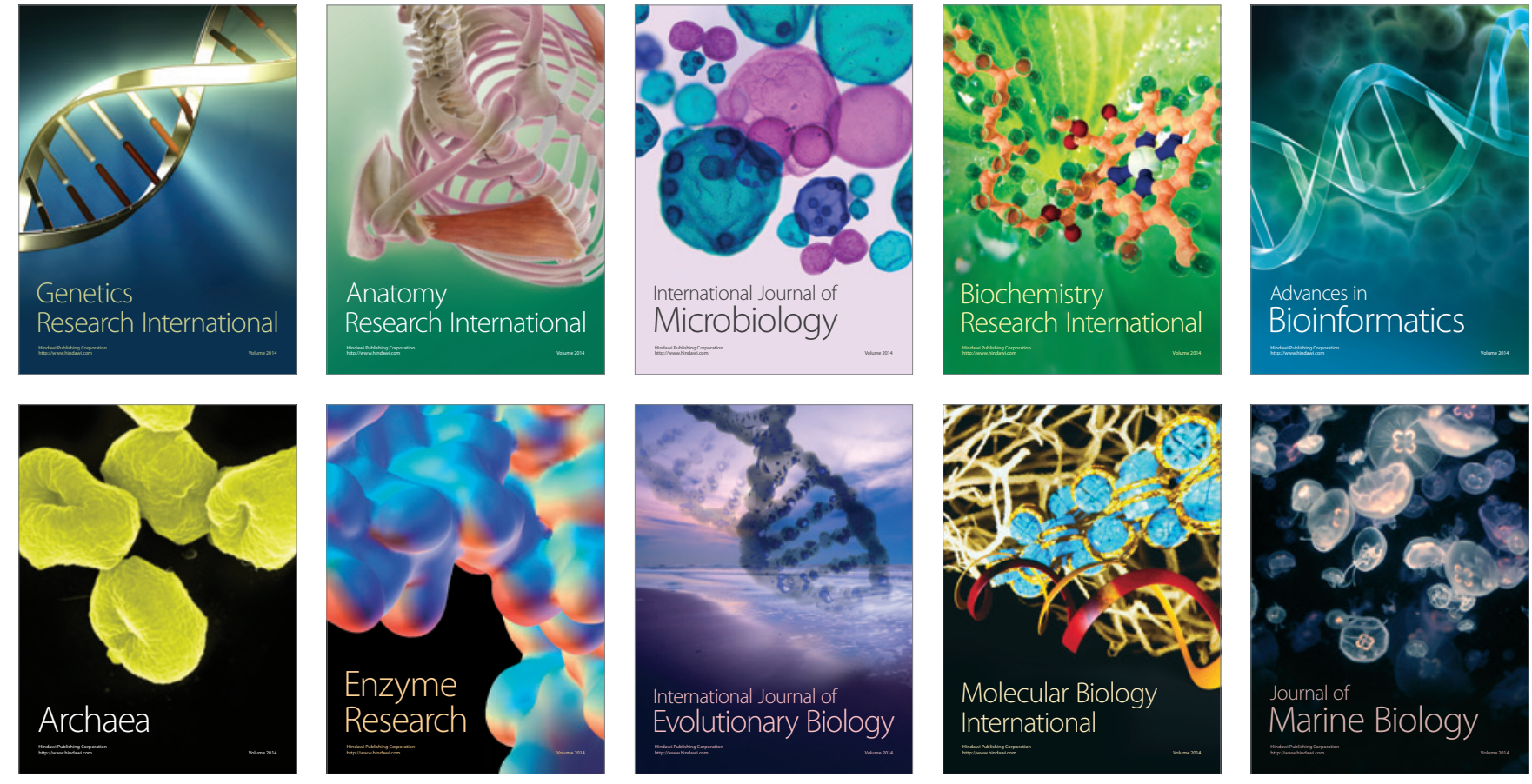